\title{
Corporate Criminal Liability in India
}

\author{
By Pradeep Kumar Sing *
}

\begin{abstract}
In 21st Century, crimes committed by corporate bodies are creating more serious challenge for criminal justice system. Some vested interests which are controlling affairs of corporate bodies misuse the corporate body for commission of criminal acts to maximise profit. Corporate body is conferred with legal personality for regulation of its functions but it does not have physical body and mind of its own, thereby, problem arises for holding corporate body as criminal, and further, in imposition of criminal liability. Corporate criminal activities badly affect environment, health, safety and infra-structure development. Corporate entities are involved in corruption, forgery, money laundering, foreign exchange violations, money laundering, tax evasions, benami property transactions and other economic offences. Proper formulation of criminal justice actions and effective enforcement of corporate criminal liabilities are modern criminal justice requirements. Corporate bodies are business entities; economic wellbeing of society, prosperity of citizenry and development of nation depend on freedom of trade, amicable business environment and least regulation of corporate entities. Hereby, in determination and imposition of corporate criminal liability for betterment of society, it is necessary to make balance between to take stern actions to tackle corporate crimes and to take care to not hamper legitimate activities of corporate bodies. Law relating to corporate criminal liability in India will be analysed in this paper.
\end{abstract}

Keywords: Criminal Justice System, Corporate crime, Corporate criminal liability, Natural person, Social wellbeing, Strict liability

\section{Introduction}

Social wellbeing is primary concern of all countries throughout the world; crime and criminality particularly socio-economic crimes create serious threat for the state and public at large needed to be effectively tackled. Corporate Crime is one specific kind of socio-economic crime committed by corporate body which is now posing a serious and graver challenge for social wellbeing in $21^{\text {st }}$ century. Corporate bodies are more organised in which expert and professional persons are appointed, thereby, to identify and detect the criminal acts are completely difficult pursuit. Traditionally in criminal justice system it is considered that the crime can be committed by natural person and criminal liability can be imposed on him as only natural persons have body and mind necessary for crime commission, committal for trial and infliction of punishment while corporate body does not have body and mind. But such a concept of criminal liability poses a serious threat for societal protection and wellbeing. Public at large have no much information

*PhD, Professor, Faculty of Law, Banaras Hindu University, Varanasi, Uttar Pradesh, India. Email: pradeep@bhu.ac.in 
regarding corporate crimes because of this reason they are not cognizant about alarming problems caused by corporate crime commission and serious impacts thereof. Reaction against corporate crime and labelling effect against corporate crime are completely non-existent. Still traditional crimes create more alarming situation for common mass and such criminal acts are taken as real crimes. Further, common members of society consider that corporate bodies perform business, manufacturing, marketing and construction activities which are legitimate activities; in some cases, such corporate bodies may have broken some regulatory rules but these are usually not taken as criminal acts but only as skilful business activities. Generally criminal acts committed by corporate entities are dealt under administrative and civil law; criminal laws are not used or exceptionally used. Traditional consideration that crime is violation of criminal law is not satisfied as corporate crimes are usually dealt under law other than criminal law. Primary and best criteria to determine nature of criminal act is impact of over society at large; on this criterion corporate crime is most serious criminal act posing serious challenge for societal existence, wellbeing of members of society and public exchequer. On this criterion corporate crime is serious crimes. Corporate crime was defined by Marshall B Clinard and Peter C. Yeager:

A corporate crime is any act committed by corporations that is punished by the state, regardless of whether it is punished under administrative, civil, or criminal law. This broadens the definition of crime beyond the criminal law, which is the only governmental action for ordinary offenders. A corporation cannot be jailed, although it may be fined, and thus the major penalty of imprisonment used to control individual law violators is not available in case of corporations per se. ${ }^{2}$

Marshall B Clinard and Peter C Yeager cleared that corporate crime is a kind of white-collar crime, but it is of particular type. ${ }^{3}$ In broader perspective white collar crime includes occupational and organisational crime both. Occupational crime term is used to denote criminal acts committed by person of respectability in course of his occupation, thereby, it refers to individual criminality committed in course of occupation; in restricted sense white collar crime term refers to such occupational crimes. Corporate crime is organisational crime and it refers to crime committed in collective, aggregate and organised manner for profit of incorporated body. Person acting in corporation may commit corporate crime (organisational crime) for which liabilities may be imposed on corporate body and doer of act or white-collar crime (occupational crime) for which liability may be imposed on doer of act only. When doer of act is working on behalf of corporate body, his act is not only his act but of corporate body also and for its corporate criminal liability may be imposed. But when such doer of act even though he is employee of corporate body has acted for his personal benefit then it will not be corporate crime and for such act occupational liability is imposed only on such employee.

Reality of crime problem has compelled to change the traditional concept of criminal liability and now corporate criminality liability is major measure to tackle

\footnotetext{
${ }^{2}$ Marshall \&Yeager (2006) at 16.

${ }^{3}$ Ibid, at 17 .
} 
effectively economic crimes ${ }^{4}$ and to protect the wellbeing of society. Whenever corporate criminal liability term is used, it refers to criminal liability of corporate body for criminal acts committed by its officers in capacity of officer of corporate body. Geis and DiMento observed about need of imposition of corporate criminal liability:

The barriers to corporate criminal liability were toppled in piecemeal fashion for a variety of reasons. Perhaps the most significant were, first, that corporations were more readily identifiable than the human malefactors within them who might have been responsible for the illegality, and the second, the enormous power being accumulated by the corporate world seemed to demand that some legal doctrine be applied to restrain its free free-wheeling and destructive acts. ${ }^{5}$

Edwin H. Sutherland studied larger and established corporate bodies on which basis he gave his opinion about crime commission that crime is also committed by person of respectability and social status and such crimes are more dangerous and harmful than traditional crimes. Sutherland gave name to such crimes as White Collar Crimes which is taken as occupational crimes; occupational crime is taken as committed by individual professional in performance of his occupation. Corporate crime is organised crime committed in organised manner by corporate body. Sutherland's study was actually about corporate crime as he studied corporate bodies, acts committed by superior executives in corporations and its harmful impact over wellbeing of public exchequer. Marshall B. Clinard and Peter C. Yeager observe:

Sutherland carried out the first empirical study in the field, White Collar Crime (1949), which should have been entitled Corporate Crime, examined the illegal behaviour of 70 of the 200 largest nonfinancial corporations. In the years since Sutherland's work, however, only limited follow-up research has been done. Relatively few articles have appeared, and they have dealt largely with antitrust violations and have been rather narrow in scope. ${ }^{6}$

David A. Frenkel and Yoram Lurie point out that there is a tight conceptual connection between the notions of moral responsibility and punishment.

It does not make sense to seek and punish a corporation for actions it was not responsible for. Subsequently, even if a corporation is indeed morally responsible for its actions and culpability has been established, the question: "what type of punishment does a corporation deserve?" still remains an open question.

In their paper they examine and analyse the current legal situation with respect to corporate criminal culpability in several countries, and hence suggest a

\footnotetext{
${ }^{4}$ Economic crimes are also called as financial crimes. Economic crimes are committed mainly committed to obtain undue advantage and always motivated with greed. Economic crimes cause serious damage to national security, public exchequer and public wellbeing. It may also be committed against individual person.

${ }^{5}$ Geis \& DiMento (2002) at 343.

${ }^{6}$ Marshall \& Yeager (2006) at 13.
} 
way of resolving the legal, ethical, and social problems associated with corporate culpability. $^{7}$

Clement Labi and Willy Tadjudge state that persons acting in legal life are not only natural persons. Alongside the latter, there are also legal persons, even though they are constituted by natural persons. In absolute terms, the legal person is fictitious, since it is set up by natural persons who act in its name and on its behalf on a daily basis.

Curiously, while personal liability is completely based on the individual, the law has made provisions to limit the liability of the shareholders to their contribution to the share capital. Such a configuration of the pattern of liability is problematic and may lead corporate directors to take unethical decisions: in fact, regardless of what the law states, they are very skilled at minimising their legal exposure. There is therefore a kind of systematic, organised and planned irresponsibility in corporate governance. Legislators should review the liability regime in legal persons, and even more so in corporations, notably by taking corporate culture seriously. Even in the corporate context, steps could be taken to ensure that those who act are subject to the legal regime of individual liability but because of the dynamics of corporate life, the task appears, unfortunately, Sisyphean. ${ }^{8}$

Major problem arises in imposition of corporate criminal liability that whether criminal liability has to be imposed on corporate body or it has to be imposed on person taking decision and operating corporate body or on both. Indian criminal justice system has established and express law for imposition of liability on both, the corporation and persons taking decision and operating corporate body. Section 11 of Indian penal Code clearly provides for non-differentiation between natural and legal person for criminal liability. Section 11 Indian Penal Code is wider enough to even impose liability on group of persons who have not got their group incorporated; hereby, in Indian law criminal liability may be imposed against legal corporate bodies and also against illegal corporate bodies such as criminal gangs, terrorist groups and unlawful assemblies.

This paper will deal with corporate criminal liability in reference to criminal acts committed by legal corporate bodies only.

\section{Impact of Corporate Crime}

Generally corporate crime is not in focus of study and concern of academicians, bureaucrats, law enforcement agency, adjudicatory body, legislature and ultimately of common mass. Crime with violence which is usually put in category of street crime creates fear of victimisation in common mass and considered as real crime and all the crime tackling policies are focused to such crimes with violence. Corporate crime is one important aspect of white collar crime which is put in category of suite crime which does not create fear of victimisation and it is generally committed by deceit. Corporate crime has never been considered as

${ }^{7}$ Frenkel \& Lurie (2002).

${ }^{8}$ Labi \& Tadjudge (2020) at 77. 
criminal acts, only recently some academicians put emphasis that it should not only be taken as criminal act but it should be taken as serious challenge for threat for wellbeing of public at large, nation and ultimately of whole world. Common public considers that corporate body only does business activities and it has no body and mind necessary for crime commission, thereby, corporate body cannot commit crime. Common mass does not aware that crime committed corporations are more dangerous, alarming and harmful. Corporate bodies have control over resources, they can hire educated and expert persons, use modes of communications and particular environment and convictions may be created that corporate bodies only do business acts and they cannot commit crime. Marshall B. Clinard and Peter C. Yeager observe:

The giant corporations possess such awesome aggregates of wealth and such vast social and political powers that their operations vitally influence the lives of virtually everyone, from cradle to grave. The work lives, and hence the health and safety, of the large part of the population are controlled directly or indirectly by the major corporations. These giants greatly affect prices and thus inflationary trends, the quality of goods, and the rate of unemployment. They can and do manipulate public opinion through the increasingly effective use of mass media, and they noticeably affect the environment...

Corporate crimes are much destructive for health, safety and security of public at large caused by greed of persons operating the corporate bodies. Economic offences committed by corporate bodies affect the whole economy of country and in some cases even of whole world too. Corporate bodies participate in infrastructure development and welfare activities, thereby, crimes committed by them affect the very life of common citizenry. Financial condition of nation is challenged by commission of Corruption, money laundering, tax evasions, non-observance of business ethics, and scams committed by corporate bodies. Production of substandard goods and providing of deficient services create serious threat for life and health of public at large. Corporate bodies have larger resources, expert persons and opportunity for criminal act commission which cause graver threat not only for one country but also to world at large. Proper and effective enforcement of corporate criminal liability is compelling need of modern criminal justice system. Corporate criminal liability is legal person's liability. Legal person term is usually used to refer legitimate corporate entities established according to provisions of law indulged in legitimate business pursuits. Society depends on corporate bodies and their business activities for proper societal functioning, catering of needs of societal members, jobs and economic prosperity of citizenry. Some activities of business entities are graver criminal activities seriously damaging the wellbeing of country and citizenry needed to be effectively tackled. In taking actions always proper care has to be taken that liability imposed should not be such which may adversely affect corporate functioning and erode the corporate business environment ultimately to society itself. Need is to make balance in taking effective

${ }^{9}$ Ibid at 3-4. 
actions against guilty corporate entities and responsible corporate officials and at the same time to encourage proper corporate business activities.

Corporate crimes are not simple criminal activities as in case of traditional crimes; traditional crime is committed against individual, only by legal fiction it is considered as committed against society; state represent the society, thereby committed against state but corporate crimes are directly committed against society, public at large, and public exchequer. Whenever corporate crime is committed, it causes serious and graver consequences over public at large. Corporate bodies may make collusion and eliminate competition and oust competitive pricing for the products, thereby more money may be charged on consumers. Where corporate body issues false and misleading statements regarding its assets and it may lead to defraud common investors, who have invested their small savings. Tax evasion is defrauding with public exchequer on which whole developmental process depends. Scam commission and corrupting public servants create corruption conducive criminogenic environment which affect sobriety and civility ultimately whole developmental process of country is affected. Hoarding of essential commodities affect the supply of necessary things for life of common public. Production and supply of substandard, spurious and adulterated drugs and food materials affect health of common mass and may cause death of thousands and thousands of persons. Non-observance of pollution prevention rules and use of unsafe manufacturing process in manufacturing units may affect completely environment which may cause health hazards, injuries and deaths of countless persons besides completely damaging the environment ultimately the whole nature.

\section{Causes of Corporate Crime}

Corporate bodies are business organisations run by natural persons who have all the characteristics of sober and civilized persons even after that it is reality of corporate functioning that various corporate bodies deviate from the normal business practices and commit violations of law enacted to regulate business activities and cause serious damage to public at large and nation ultimately to world at large. In such situation it becomes compelling to identify causes of corporate crime commission. Analysis of causation of corporate crime commission is crucial for enactment of law and imposition on corporate criminal liability for effective tackling of economic crimes committed by corporate bodies. Anomie Theory and Strain Theory developed by Robert Merton taken together with Differential Association Theory given by Edwin $\mathrm{H}$ Sutherland provide explanation for crime commission by persons controlling the affairs of corporate bodies which is also taken as crime commission by corporate body itself. In modern era whether it is legal person or natural person, everyone is undergoing strain and stress due to goal and legitimate means disparity; legitimate means available are not sufficient to satisfy goals (desires which have taken shape of passion). The realisation of financial success purportedly is open to all, but actually opportunities this goal is not distributed equally within social structure. This disparity between goal and 
means creates strain. ${ }^{10}$ Corporate entities are established with certain objectives, thereby, corporate entities are always goal oriented. ${ }^{11}$ For corporate bodies also there is disparity between corporate goals and legitimate corporate means. Every corporate body has financial goals which may be broadly taken as profitability, competitiveness and market share expansion. Financial success is always connected with corporate success. Even when corporate body is successful and well established, it has to be continued in competition, augment profits and expand its market share. When goal cannot be achieved by legitimate means then strain compel corporate body to achieve it by adopting illegitimate means. Strain is not only inter-organisational but also intra-organisational. ${ }^{12}$ Inter-organisational strain is competition with other corporate bodies for maximisation of profit and expansion of market share. Intra-organisational strain arises due to competitions of sub-units within the corporate body and it creates internal performance pressure and ultimate consequence is practicing illegality.

Only strain due to disparity between corporate goal and means is not sufficient for corporate crime commission but it is necessary that natural persons acting on behalf of corporate body have mental preparedness for corporate crime commission and specialisation in illegitimate techniques for this purpose. Edwin $\mathrm{H}$ Sutherland extended his Differential Association Theory to explain white collar crime also and according to which white collar crime is also a learnt behaviour which is learnt in communication with the persons who are already practicing it. Edwin $\mathrm{H}$ Sutherland opined that white collar has its genesis in the same general process as other criminal behaviour, namely differential association. ${ }^{13}$ Corporate officials having corporate strain learn corporate crime commission from the corporate officials already indulged in corporate crime commission; such learning may be through direct or indirect communication. In such learning corporate official learns and develops drive and rationalisation for corporate crime, and then learns techniques of commission of such acts. Edwin H Sutherland observed:

Businessmen are not only in contact with definitions which are favourable to white collar crime but they are also isolated from and protected against definitions which are unfavourable to such crime. ${ }^{14}$

Greed and acquisitiveness are main causes of corporate crimes. Now persons in modern industrialised and urbanised society have insatiable greed and obsession to have possession of physical commodities. Honest means may not be sufficient to satisfy such insatiable greed and acquisitiveness for physical commodities. Working through particularly productions and business activities through corporate bodies are distinctive features of capitalist society. Dutch criminologist William A. Bonger gave opinion about crime committed by richer person. Bonger ${ }^{15}$ opined that capitalism give rise to egoism (selfishness increases) and altruism comes to an

\footnotetext{
${ }^{10}$ Merton (1964) at 218.

${ }^{11}$ Finney \& Lesieur (1982) at 269.

${ }^{12}$ Ibid, at 271-272.

${ }^{13}$ Sutherland (1949) at 234.

${ }^{14} I d$ at 247.

${ }^{15}$ Bonger (1916).
} 
end; in capitalism egoism grows on cost of altruism. Bonger opined that in capitalism class of person and person becomes selfish and has jealousy. Due to misery working class commits crime and similarly bourgeoisie due to capitalism have avarice and commit crime. Altruism is major check over criminality; it has become weaker, thereby, egoism and resultant greed and jealousy have created conducive environment of corporate crime. Due to the increase in egoism and decrease in altruism, person's bond with society becomes weaker. When attachment with society and societal members is stronger, crime particularly which may cause serious damage cannot be committed but when such bond is weaker than person for attaining his goal to become richer may commit any kind of criminal act. Travis Hirschi gave Control Theory to explain the crime causation and he opined that delinquent acts result when an individual's bond to society is weak or broken. ${ }^{16}$ Stronger bond to society and member of society create conducive situation for a person to behave in conformist behaviour. Bond of person with society contains four inter-related components - attachments, commitments, involvements and beliefs. In these components main component is attachment to society and fellow societal members.

Public reaction is major check against crime and criminality, thereby, its presence and absence are one main cause of crime and criminality. Public consciousness regarding harmful act determines enactment of penal law for prescribing punishment and dealing with effectively to protect the citizenry. Common citizenry does not have adequate information about harmful acts committed by corporate bodies and its serious impacts; common person only consider that business and production acts are committed by corporate bodies. Further, citizenry also consider corporate bodies have no body and mind, thereby, they can never commit crime. Generally, corporate crime is not committed directly against individual. Common public only take it that if any illegality is committed it may be officials of corporate bodies, and further, even such a case it may be only a simple tax evasion or irregular business activities which may be tackled by administrative, civil or administrative regulation. Such absence of public reaction affects criminal justice actions against serious corporate criminality. Due to absence of public reaction against corporate crime reputation of corporate body and persons responsible to run corporate bodies is not affected. Further, law enforcement agencies have no public pressure for taking actions under criminal law against the corporate bodies; action may not be taken at all or if taken, it may be under civil, administrative or taxation laws and it may be shown that for actions have been taken against corporate body. In such situations corporate body and persons responsible for operating it may have conducive crime committing environment and even after that do not have fear of criminal liability and loss of reputation.

\footnotetext{
${ }^{16}$ Hirschi (1969) at 16.
} 


\section{Corporate Criminal Liability in India}

Harmful acts committed by corporate bodies are either not covered by provisions contained in criminal law or in some cases when such acts are declared crimes under criminal law, in almost cases acts are also covered under civil, taxation or administrative law. In all such situations normally actions against such harmful acts are taken under law other than criminal law. On the basis of harmful impact of harmful acts committed by corporate bodies, it has always to be treated as criminal acts regardless whether acts are committed in violation of criminal law or actions are taken under provisions of criminal law or actions are taken under some other law. Corporate bodies are provided with legal personality and various permissions under the provisions of law for benefit of society at large, thereby corporate bodies cannot be permitted to commit acts dangerous for society itself. Corporate bodies commit crime due to economic causation; their objective of crime commission is maximisation of profit at any cost, and consequences of their crime commission is greater economic loss to society, nation and ultimately to world at large. On the basis of economic causation, economic goal and economic consequences, corporate crimes are put in category of economic crimes. Such dangerous and serious corporate harmful acts to protect the society can only be tackled by effective imposition of criminal liability.

Corporate bodies are operated and business activities are conducted by experienced and expert professionals in planned and organised manner by use of modern know-how; thereby collection of evidences to prove intention or knowledge in reference to crime commission is very difficult. At the same time for tackling problem of economic crime and to protect the society it is necessary that corporations and its human agency involved in corporate crime must be penalised. For this purpose, strict liability rule is prescribed according to which on proving of commission of act prohibited by law, presence of mental element is presumed. Further, for imposition of corporate criminal liability besides strict liability, law also provides absolute liability and imputed liability rules. Corporate criminal laws on proving of prohibited act commission (actus reus) shift the burden of proof from prosecution to alleged corporate entity, and further, provide the presumption clause regarding culpable mental element (mens rea). In some cases, presumption applied for mental element is rebuttal presumption and, in some cases, conclusive presumption. Where presumption applied is rebuttal, nature of corporate criminal liability is strict liability and where presumption is conclusive presumption, nature of corporate liability is absolute liability. Sometimes confusion is raised that in case of corporate crime mental element is not requisite element but it has to be cleared that corporate crime is also one sort of crime, thereby, mental element is necessary; only difference is that it does not need to be proved through adducing evidences but presumed.

Corporate entities perform business activities through agencies of natural persons; in such situation problem arises in affixing criminal liability that whether criminal liability has to be imposed on natural person only or it has to be imposed on corporate body only or it has to be imposed on both. Corporate bodies have no mind and physical body, thereby naturally harmful criminal acts can be committed 
by natural person. To impose criminal liability on corporate body it has to be decided that crime was committed by natural person then on establishing relations of crime and natural person with corporate body, criminal liability can be imposed on corporate body. Corporate crime commission is depending on crime commission by natural person acting as human agency of corporate body. Corporate body works through mind and body of the persons who perform the work for it. But the mind of any person working for corporate body cannot be taken as mind of corporate body, according to standard procedure used for corporate functioning it is considered that corporate body run under 'controlling and willing mind' of person having control of such corporate body. Thereby, when such persons controlling the affairs of corporate body have mens rea or knowledge, it is attributable to corporate body; corporate body, natural person committing the criminal acts and persons controlling the affairs of corporate body may be held criminally liable. In larger corporate bodies usually, excuses are taken by higher positioned persons that affairs of corporate body are decentralised and employee has committed criminal act on his own and only he has to be penalised. To avoid corporate criminal liability generally attempts are made to show that acts are committed by employee but he was not authorised to take decision on behalf of corporate body. For imposition of corporate criminal liability, a major issue has to be decided that whether crime was committed by employee concern in his individual capacity, in such situation only will be criminally liable or crime is committed by him as employee of corporate body and for its criminal liability will be imposed on doer of crime, person controlling the affairs of corporate body and also the corporate body. When doer of crime has committed crime in capacity of employee of corporate body, imputed liability is imposed on person controlling the affairs of corporate body and corporate body. It is a kind of constructive liability rule and a sort of vicarious liability rule. General rule of criminal liability is well established that a person who has committed crime, only he is liable and he is liable for his own criminal act. But imputed liability rule is exception; on crime commission by employee in reference to affairs of corporate body, it is considered that crime is also committed by corporate body. In case of Standard Chartered Bank v. Director of Enforcement ${ }^{17}$ Supreme Court settled the law that a company can be prosecuted and convicted for even that offence for which minimum sentence of imprisonment is prescribed. A corporate body cannot avoid liability on the ground that punishment prescribed for offence is imprisonment and it has no body. When for any offence imprisonment and fine both are prescribed punishment, corporate entity will be inflicted with fine only. Natural persons liable for corporate crime may be punished with punishments prescribed by penal provisions. In Iridium India Telecom Ltd. v. Motorola Inc. ${ }^{18}$ Supreme Court decided that corporate criminality can be imposed even for that offence for which mens rea is essential requisite. Court decided that attribution and imputation rule of applicable, thereby, criminal intent of the 'alter ego' of the company/body corporate i.e. the person or group of persons that guide the business of the company, would be imputed to the corporation. In Sunil Bharati Mittal v. Central Bureau of

\footnotetext{
${ }^{17}$ AIR 2005 SC 2622

${ }^{18}$ AIR 2011 SC 20
} 
Investigation ${ }^{19}$ Supreme Court reiterated Iridium case decision regarding attribution and imputation means 'alter ego'; whenever person controlling the affairs of corporate body have mens rea and have done criminal act, it is attributed that company was also actuated with mens rea and it is imputed that company itself committed the criminal act. In Sunil Bharati Mittal Case Supreme Court observed:

No doubt, a corporate entity is an artificial person which acts through its officers, directors, managing director, chairman etc. If such a company commits an offence involving mens rea, it would be normally the intent and action of that individual who would act on behalf of the company. It would be more so, when the criminal act is that of conspiracy. However, at the same time, it is cardinal principle of criminal jurisprudence that there is no vicarious liability unless statute specifically provides so. $^{20}$

In Sunil Bharati Mittal Case Supreme Court decided that in India vicarious liability rule is not applicable for imposition of criminal liability unless by specific and express provision of law vicarious liability has been imposed for crime commission. For application of strict liability, absolute liability and imputed liability rules, it is necessary to establish relationship between natural person doing the harmful act and corporate body. In this regard 'controlling and wilful mind' test is used but it may not be appropriate in all the situations, therefore, some more tests are used like benefit test and due diligence test. When act committed by employee is beneficial for corporate body and further benefit is also entertained by such corporate body knowingly that it was criminal act. In this regard it is pertinent to identify whether corporate body has envisaged due diligence mechanism to avoid crime commission; presence or absence of due diligence mechanism is crucial criterion. When due diligence mechanism is effectively available in the corporate body and it is identified that some employee of corporate body committed some criminal act, corporate body has to take action against such guilty person. In case no action is taken, clearly indicative that corporate body has taken benefit of crime commission and in such situation, crime will be treated as committed by corporate body itself, for its corporate criminal liability may be imposed. Some legislation may be analysed to identify corporate criminal liability legal regime in India.

Indian Penal Code (hereinafter referred as IPC) was enacted more than 160 years ago in $1860 \mathrm{AD}$, and further, it mainly deals with traditional crime but even after that IPC is developed and enlightened legislation which in addition to imposition of criminal liability on natural person also provides sufficient provisions to impose criminal liability on corporate bodies. Section 2 IPC declares that every person whoever commits violations of provisions of IPC shall have criminal liability. Section 11 IPC explains that who may be taken as person; for crime commission such persons according to Section 2 IPC criminal liability may be imposed. Provisions contained in Section 11 IPC provides 'The word 'person' includes any company or association, or body of persons, whether incorporated or

\footnotetext{
${ }^{19}$ AIR 2015 SC 923

${ }^{20} I d$ at 941
} 
not', thereby, it clears that besides natural person legitimate corporate body and also criminal enterprise are person on whom criminal liability may be imposed. Thus, in IPC criminal liability is imposable on natural person, legal person and also on illegal criminal person (here term illegal criminal person is used to refer to criminal gangs ). Sometimes confusion arises that Section 11 IPC only talks about legal person but proper analysis may show that Section 11 IPC is very progressive and wider provision which provides for natural person, legal person and also criminal Gangs. Criminal law in India since 1860 AD with enactment of IPC provides for corporate criminal liability.

Corruption is a major problem affecting the whole society. For effective check on corruption, corporate criminal liability is one of the important requisites. Prevention of Corruption Act 1988 has been completely amended and changed in 2018 to make the law effective to deal with corruption. If in any corruption case giver of undue benefit is commercial organisation, third proviso to Section 8 (1) of Prevention of Corruption Act prescribes only fine as punishment imposable on such commercial organisation. Corporate criminal liability is imposed on commercial organisation when any person associated with such corporate body gives undue benefit to public servant. In Section commercial organisation is defined in Section 9 (3) of the Act that it refers to corporate body incorporated in India doing business in India or outside, corporate body incorporated outside India carrying on business wholly or partly in India, and partnership firms or association of persons formed in India doing business in India or outside India or such firm or association formed outside India doing business wholly or partly in India. Commercial organisation will have responsibility only when such person comes under ambit of person associated to commercial organisation. Person associated to commercial organisation is that person who performs services for or on behalf of commercial organisation $^{21}$; Explanation 2 to Section 9 directs that for deciding such relation between natural person who gave undue benefit to public servant and commercial organisation all the relevant circumstances shall be taken into consideration. Commercial organisation may take defence to avoid criminal liability that such organisation has adequate procedure to prevent the associated person from doing such kind of criminal act of giving undue benefit. ${ }^{22}$ Whenever commercial organisation is found involved in giving undue benefit to public servant Section 10 imposes imputed liability on director, manager, secretary or other responsible officer subject to proving of consent or connivance for such act. all the natural person involved in giving of undue benefit are liable for punishment for term of imprisonment and fine both while corporate body is liable for fine only.

Prohibition of Benami Property Transaction Act 1988 is crucial legislation to deal with problem of benami property and thereby to effectively tackle corruption in India. In Section 62 of the Act for commission of any act relating to benami property by company corporate criminal liability is imposed on company, and further, imputed liability is imposed on every person in-charge and controlling the conduct of business of the company. Such natural person may avoid his liability

\footnotetext{
${ }^{21}$ Prevention of Corruption Act, 1988, Section 9 (3) (c)

${ }^{22}$ Prevention of Corruption Act, 1988, Proviso to Section 9 (1)
} 
by adducing evidences that he had no knowledge of such contravention relating to benami property. On proving of involvement of company in benami property transaction Section 62 (3) of the Act provides that on proving of consent or connivance or negligence the director, manager, secretary shall also be deemed to be guilty. In Section 56 (1) Black Money (Undisclosed Foreign Income and Assets) and Imposition of Tax Act 2015 similar provisions are provided for imposition of corporate criminal liability under which for commission of offence by company criminal liability is imposed on company and persons controlling the business of company at the time of commission of offence. Similarly, on commission of acts relating to money-laundering Section 70 of Prevention of Money-Laundering Act 2002 imposes corporate criminal liabilities on company and persons controlling the affairs of company. Due diligence criterion is always important in corporate criminal liability, it is identifiable in every legislation imposing corporate criminal liability on corporate bodies and officers of such corporate bodies. In every provision imposing corporate criminal liability on corporate body and its officers deeming provisions are provided through which legal fiction are created ultimately by which presumption are made regarding participation in commission of criminal acts, thereby, strict and absolute liabilities are imposed on corporate body and its officers. In Aneeta Hada v. Godfather Travels \& Tours $(P)$ Ltd. $^{23}$ Supreme Court observed:

We have referred to the aforesaid authorities to highlight that the company can have criminal liability and further, if a group of persons that guide the business of the companies have the criminal intent, that would be imputed to the body corporate [...]. The said provision clearly stipulates that when a person which is a company commits an offence, then certain categories of persons in charge as well as the company would be deemed to be liable for the offences under Section 138. Thus statutory intendment is absolutely plain.

As is perceptible, the provision makes the functionaries and the companies to be liable and that is by deeming fiction. A deeming fiction has its own significance.

Female sex determination in womb, foeticide and infanticide are major challenges for criminal justice system, to check such problems some penal statutes are enacted and criminal liabilities are imposed. Corporate criminal liabilities are imposed on hospitals, persons working in hospitals and persons controlling the affairs of hospitals. Section 22 of Pre-Conception and Pre-Natal Diagnostic Techniques (Prohibition of Sex Selection) Act 1994 (PCPNDT Act) declares giving advertisement for pre-natal sex determination as an offence and in case of commission of offence imposes liability on advertising company, hospital and medical practitioner. Whenever any clinic is indulged or permitted to use it for sex determination, it is liable for punishment. ${ }^{24}$ Section 3-A of Act imposes restriction on manufactures and dealers not to supply any ultra-sound machine or scanner or any equipment which may be used in sex detection unless hospital or other institution is registered under the PCPNDT Act. Whenever provisions of PCPNDT

\footnotetext{
${ }^{23}$ AIR 2012 SC 2795

${ }^{24}$ Pre-Conception and Pre-Natal Diagnostic Techniques (Prohibition of Sex Selection) Act 1994, Section 23.
} 
Act are violated, Section 26 of PCPNDT Act provides for imposition of criminal liability on medical practitioner, other employees of clinic, and corporate criminal liability on the clinic, other corporate bodies and person responsible for affairs of the clinic. For imposition of liability presumption clauses are provided in form of deeming provision. Transplant of Human Organ Act 1994 (THO Act) is crucial legislation to tackle the problem of commercialisation of organ transplant. Advertising company, hospital or any other person giving advertisement for supply of human organ are liable and criminal liability is imposed u/s 19 THO Act. Section 21 expressly specifies that hospital is a corporate body and for illegal organ removal and transplant corporate criminal liabilities are imposed on corporate body and persons regulating affairs of corporate body. For imposition of punishment on hospital and officers of such hospitals deeming provisions, thereby, presumption clauses are applicable. When officers of hospital prove that they had no knowledge or they exercised due diligence to prevent commission of such offence, they may not be liable. Similar provisions for imposition of corporate criminal liability are provided in Section 34 of Drugs and Cosmetics Act 1940, u/s 9 of Drugs and Magic Remedies (Objectionable Advertisements) Act 1954, Section 10 of Essential Commodities Act 1955, Section 14 of Protection of Civil rights Act 1955, Section 33 Arms Act 1959, Section 7 of Indecent Representation of Women (Prohibition) Act 1986 and Section 42 of Foreign Exchange Management Act 1999.

Generally, evidences are not available or very few evidences are available in all the socio-economic crimes. Corporate crime is one major area of socioeconomic crimes. Socio-economic crimes particularly corporate crime is much serious challenge for individual, social and national wellbeing, therefore to tackle the problem presumption clauses are provided, legal fictions are created by prescription of deeming provisions which implicitly shift the burden of proof from prosecution to accused. In addition to above express provisions for shifting of burden of proof are also provided in various enactments. Section 8 of Conservation of Foreign Exchange and Prevention of Smuggling Activities Act 1974 provides that when any person is found property more than his known sources or illegally acquired and notice is given, it will be burden of proof of such person that property is not of such kind. In Section $10 \mathrm{C}$ of Essential Commodities Act 1955 provisions are given expressly prescribing for rebuttal presumption regarding culpable mental state in any prosecution under this Act. Section 14 of Essential Commodities Act express provisions for shifting burden on proof to accused is provided that on prosecution of any person for violation of order under Section 3 of Act, such person will have burden of proof that he has permit or licence for the alleged act.

Corporate crimes are completely different from traditional crimes. Traditional crimes are visible; usually create reactive emotions in common members of society. Further, in traditional crimes clues and evidences are properly available which may be collected by common investigating agencies and evidences may be produced by common prosecution agency. Corporate crimes are not visible, committed with business garbing, thereby social reaction against corporate crime is completely absent which affects information availability regarding crime commission, branding and stigmatisation of corporate body and natural person 
working for such corporate body. Corporate crimes pose serious challenge for members of society, society, nation and even whole world; such criminality is needed to be tackled at any cost. For tackling corporate crime in India criminal liability is prescribed but major problem in this regard is clues and evidences are not available. In such situation traditional criminal law rules are modified, strict, absolute and imputed liability rules are prescribed; presumption clauses, shifting of burden of proof and deeming provisions are provided.

\section{Concluding Remarks}

In present era of industrialised business oriented market based society, it is not possible for a natural person to do various acts individually particularly manufacturing, service providing, marketing and other business activities; now natural persons form corporate body to perform such business activities. Works performed by corporate bodies affect the individuals, society and nation, thereby, need is felt to regulate the activities of and works of corporate body. For regulation of activities of corporate bodies are declared as legal person. Most effective measure for regulation of behaviour of any person is criminal justice system. All the actions of corporate bodies and its employees which cause serious impacts over public at large, society and nation are declared as crime and criminal liability is imposed. Corporate crimes are much dangerous criminal activities committed by corporate bodies and natural persons controlling the corporate bodies causing serious consequences for public health, development of nation and financial wellbeing of whole country, even whole world is affected by such corporate crime commission. Corporate bodies are formed for doing the business, thereby, it has financial goal of earning profits. For earning profit market share expansion is necessary requirement and it also forms the corporate goal. Legitimate means available may not be sufficient to achieve the goal; such situation creates adaptation. Strain caused induces persons controlling the affairs of corporate body to learn use of illegitimate means to achieve the goal, thereby, strain becomes major causation for learning the techniques to commit corporate crime.

For effective dealing of any crime problem, it is necessary that common citizenry and criminal, both, should consider that the act committed is crime and it is wrongful. When public consider act as criminal act, only then it will react and cooperate with law enforcement agencies. A person committing delinquent activities can only be reformed, when he will take himself as wrongdoer. Corporate criminal acts are considered by public and person controlling the affairs of corporate body as business acts performed in skilled way. Need is to change the whole such notion and for it not only such acts be declared as crime but also effective punishment has to be inflicted. All the measures have to be taken for branding of such acts as criminal acts.

It is evident that the corporate crimes cause serious impacts over public at large not only within the country but also beyond the country. For tackling problem of economic crime and to protect the society it is necessary that corporations and its human agency involved in corporate crime must be penalised. But at the same 
time corporate entities are indispensable for the society; corporate entities perform business, manufacturing, marketing, transportation, banking, service providing, infra-structure development and welfare activities. Proper functioning of corporate bodies ensures employment availability and economic prosperity of the citizenry and country. In such situation a very strict penal action against corporate entities may also adversely affect the society need is to make balance in the penal actions. Criminal liability has to be imposed; in this reference on guilty natural person responsible for crime commission, whether he himself committed or controlling the operations of corporate entities, severe punishments including corporal and monetary punishments have to imposed by which such persons having potentiality and mentality to commit himself and also to use corporate body for crime commission at the cost of wellbeing of society should have a lesson. Criminal liability has also to be taken against corporate body in such manner that corporate activities has to be effectively and properly regulated and at the same time corporate legitimate activities have not to be affected. Corporate entities do not have physical body, thereby corporal punishment cannot be imposed. Generally, in almost cases liabilities imposed on corporate entities are monetary and usually fine is imposed which is considered by common persons as lenient punishment. Fine does not create labelling effect. Two pronged actions have to be envisaged in criminal laws dealing with corporate crimes, firstly, strict and stern corporal punishment besides monetary punishment against doer of criminal act and person controlling the affairs of corporate body, and secondly, monetary punishment against corporate body. Some other actions may also be used against corporate body to tackle corporate crime like closure of business till due observance of legal regulations which may cause fear of loss of business, and publicizing of name on proving of crime commission which may cause fear of loss of reputation and goodwill.

\section{References}

Bonger, W.A. (1916). Criminal and Economic Conditions. Boston: Little, Brown, and company.

Frenkel, D.A. \& Y. Lurie (2002). 'Culpability of Corporation - Legal and Ethical Perspectives' in Criminal Law Quarterly 45:465-487.

Geis, G. \& J.F.C. DiMento (2002), 'Empirical Evidence and Legal Doctrine of Corporate Criminal Liability" in Am. J. Crim, L. 29(3):341-376.

Hirschi, T. (1969). Causes of Delinquency. Berkeley: University of California Press.

Finney, H C \& H.R. Lesieur (1982), "A Contingency Theory of Organisational Crime”, In S B Bacharak (ed) Research in The Sociology of Organisation, Vol.1, pp. 255-299. Greenwich: JAI Press.

Labi, C.\& W. Tadjudge (2020). 'The Facelessness of Evil: Towards a Rationale for Corporate Criminal Liability' in Athens Journal of Law 6(3):283-298.

Marshall B.C. \& P.C. Yeager, Corporate Crime, Transaction Publishers, New Burswick USA, 2006, Originally Published by Free Press, New York, 1980.

Merton, R.K. (1964). 'Anomie, Anomia, and Social interaction: Contexts of deviant behavior' in R.M. Clinard (Ed.) Anomie and Deviant Behavior, pp. 213-242. New York: The Free Press. 
Sutherland, E.H. (1949). White Collar Crime. New York: Holt, Rinehart and Winston.

\section{Cases}

Standard Chartered Bank v. Director of Enforcement AIR 2005 SC 2622

Iridium India Telecom Ltd. v. Motorola Inc. AIR 2011 SC 20

Sunil Bharati Mittal v. Central Bureau of Investigation AIR 2015 SC 923

Aneeta Hada v. Godfather Travels \& Tours (P) Ltd. AIR 2012 SC 2795

\section{Legislations}

Arms Act, 1959

Black Money (Undisclosed Foreign Income and Assets) and Imposition of Tax Act, 2015

Conservation of Foreign Exchange and Prevention of Smuggling Activities Act, 1974

Drugs and Cosmetics Act, 1940

Drugs and Magic Remedies (Objectionable Advertisements) Act, 1954

Essential Commodities Act, 1955

Foreign Exchange Management Act, 1999

Indecent Representation of Women (Prohibition) Act, 1986

Indian Penal Code

Pre-Conception and Pre-Natal Diagnostic Techniques (Prohibition of Sex Selection) Act, 1994

Prevention of Corruption Act, 1988

Prevention of Money-Laundering Act, 2002

Prohibition of Benami Property Transaction Act, 1988

Protection of Civil rights Act, 1955

Transplant of Human Organ Act, 1994 
